\title{
Methylotrophic methanogenesis governs the biogenic coal bed methane formation in Eastern Ordos Basin, China
}

\author{
Hongguang Guo $\cdot$ Zhisheng Yu $\cdot$ Ruyin Liu • \\ Hongxun Zhang $\cdot$ Qiding Zhong $\cdot$ Zhenghe Xiong
}

Received: 23 October 2011 /Revised: 29 December 2011 / Accepted: 2 January 2012 / Published online: 28 January 2012

(C) Springer-Verlag 2012

\begin{abstract}
To identify the methanogenic pathways present in a deep coal bed methane (CBM) reservoir associated with Eastern Ordos Basin in China, a series of geochemical and microbiological studies was performed using gas and water samples produced from the Liulin CBM reservoir. The composition and stable isotopic ratios of CBM implied a mixed biogenic and thermogenic origin of the methane. Archaeal 16S rRNA gene analysis revealed the dominance of the methylotrophic methanogen Methanolobus in the water produced. The high potential of methane production by methylotrophic methanogens was found in the enrichments using the water samples amended with methanol and incubated at 25 and $35{ }^{\circ} \mathrm{C}$. Methylotrophic methanogens were the dominant archaea in both enrichments as shown by polymerase chain reaction (PCR)-denaturing gradient gel electrophoresis (DGGE). Bacterial 16S rRNA gene analysis revealed that fermentative, sulfate-reducing, and nitrate-reducing bacteria inhabiting the water produced were a factor in coal biodegradation to fuel methanogens. These results suggested that past and ongoing
\end{abstract}

H. Guo $\cdot$ Z. Yu $(\bowtie) \cdot$ R. Liu $\cdot$ H. Zhang

College of Resources and Environment,

Graduate University of Chinese Academy of Sciences,

19 A Yuquan Road,

Beijing 100049, People's Republic of China

e-mail: yuzs@gucas.ac.cn

\section{H. Zhang}

Research Center for Eco-Environmental Sciences,

Chinese Academy of Sciences,

18 Shuangqing Road,

Beijing 100085, People's Republic of China

Q. Zhong $\cdot$ Z. Xiong

Food Analysis using Isotope Technology Lab, China National

Research Institute of Food and Fermentation Industries,

32 Xiaoyun Road,

Beijing 100027, People's Republic of China biodegradation of coal by methylotrophic methanogens and syntrophic bacteria, as well as thermogenic CBM production, contributed to the Liulin CBM reserves associated with the Eastern Ordos Basin.

Keywords Coal bed methane - Methanogenesis · Deep subsurface environment · Ordos Basin

\section{Introduction}

Coal bed methane (CBM) is a major clean energy resource worldwide and which is being intensively developed in many countries. CBM is generally understood to be formed by microbial degradation of coal (biogenic origin) or thermal decomposition of coal (thermogenic origin), which is typically analyzed by such standard geochemical technologies as plotting hydrocarbon gas composition $\mathrm{C}_{1} /\left(\mathrm{C}_{2}+\mathrm{C}_{3}\right)\left(\mathrm{C}_{1}-\mathrm{C}_{3}\right.$, methane, ethane, propane) versus stable carbon isotope ratios of methane $\delta^{13} \mathrm{C}-\mathrm{CH}_{4}$ (Bernard et al. 1978). Biogenic CBM has been reported to be present in various reservoirs with mixed biogenic and thermogenic CBM or predominantly biogenic CBM, e.g., in the San Juan Basin (Scott et al. 1994), in the Illinois Basin (Strapoć et al. 2007), and in the Powder River Basin (Flores et al. 2008). It is generally accepted that biogenic CBM is the end product of coal biodegradation by methanogenic archaea and syntrophic bacteria inhabiting coal beds. These microorganisms are essential for artificially stimulating the regeneration of biogenic CBM (Green et al. 2008; Harris et al. 2008; Pfeiffer et al. 2010). Thus, it is essential to explore the existence of biogenic CBM to more fully understand the microorganisms involved in the formation of biogenic CBM.

Some systemic studies have evaluated the microbial communities inhabiting the CBM reservoirs containing biogenic 
CBM. Sampling gas and water produced in the Illinois Basin, Strapoć et al. $(2007,2008)$ demonstrated the predominance of biogenic CBM formed via hydrogentrophic methanogenesis by a population of Methanocorpusculum using geochemical and microbiological methods. It was found that methanogens were also present in water produced from other reservoirs, e.g., the Powder River Basin (Green et al. 2008), the Gippsland Basin (Midgley et al. 2010), and the Alberta Basin (Penner et al. 2010). Furthermore, enrichment studies demonstrated that native methanogens indicated the production of methane by supplementing water samples with nutrients and substrates for methanogens (Green et al. 2008; Midgley et al. 2010). It has been reported that acetotrophic and hydrogenotrophic methanogeneses were the dominant pathways for the production of methane in CBM reservoirs (Strapoć et al. 2011). However, as one of the pathways for producing methane by methanogens, methylotrophic methanogenesis was rarely reported in CBM formation (Shimizu et al. 2007; Strapoć et al. 2010).
The Ordos Basin, situated in central China within the Yellow River drainage basin (Fig. 1), is one of the largest CBM reservoirs and a principal target area for CBM exploration and development in China. However, there is limited understanding on the origin of CBM and of the microbial communities related to CBM in the Ordos Basin. In this study, we sought preliminary identification of the origin of CBM using the chemical and stable isotopic signatures of CBM. Culture-independent and culture-dependent methods were also used to explore the pathway of biogenic CBM formation in a deep CBM reservoir associated with the Ordos Basin.

\section{Materials and methods}

Study site and sample collection

Water and gas samples were collected from deep wells in the Liulin District which is located in the middle part of the

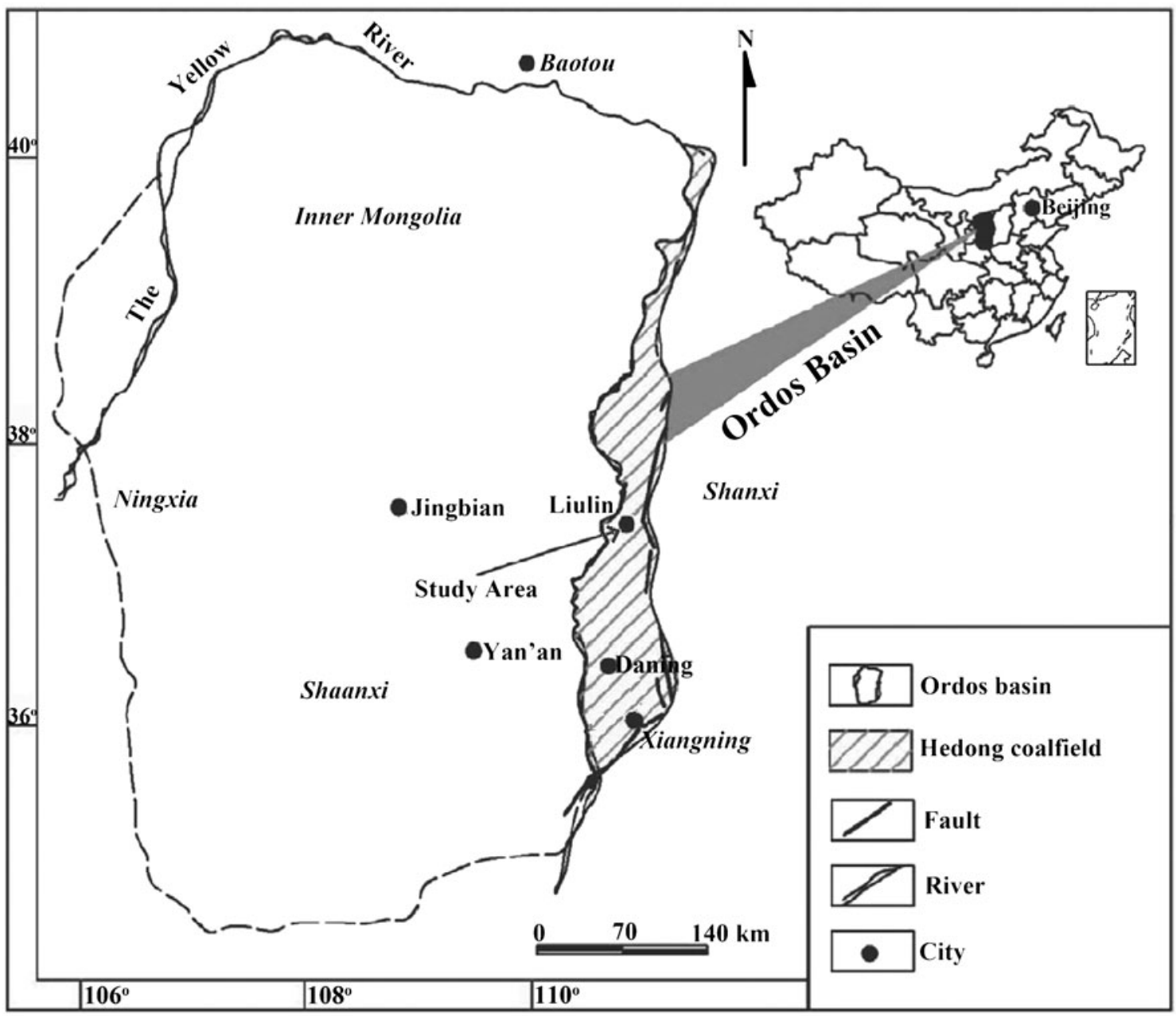

Fig. 1 Location of the Liulin District in China. The map is modified from Ding et al. (2011) 
Eastern Ordos Basin (Fig. 1). It is the first experimental base of CBM exploration and development in China ( $\mathrm{Su}$ et al. 2003). The wells were drilled down to about $700 \mathrm{~m}$ below the ground surface and constructed with tight steel pipes. Water samples were collected from five CBM-producing wells (SXLL-2, SXLL-3, SXLL-4, SXLL-6, and SXLL-9). To prevent contamination by air and steel pipes, the water produced was continuously pumped for more than 5 days before sampling. Water samples were collected into autoclaved glass bottles, carefully maintaining air in the headspaces clean. Bottles were then tightly sealed and immediately transported on ice to the laboratory. The gas samples from four CBM-producing wells (SXLL-2, SXLL-3, SXLL-6, and SXLL-9) were collected at the well sites through water displacement into inverted bottles. The bottles were tightly sealed with butyl rubber stoppers underwater to prevent air contamination.

Physical and chemical analysis

Cations were determined by utilizing an inductively coupled plasma optical emission spectrometer (Spectro Analytical Instruments, Kleve, Germany). Anions were determined by ion chromatography (Metrohm Ltd, Herisau, Switzerland), except that $\mathrm{NH}_{4}{ }^{+}$was analyzed by utilizing a colorimetrical method. Concentrations of $\mathrm{H}_{2}, \mathrm{O}_{2}, \mathrm{CO}_{2}, \mathrm{~N}_{2}, \mathrm{CH}_{4}, \mathrm{C}_{2} \mathrm{H}_{6}$, and $\mathrm{C}_{3} \mathrm{H}_{8}$ in the gas samples were determined using the Agilent 3000A Micro gas chromatograph (GC) (Agilent Technologies).

The stable isotopic ratios of the ${ }^{13} \mathrm{C}\left(\delta^{13} \mathrm{C}\right)$ of the $\mathrm{CH}_{4}$ and $\mathrm{CO}_{2}$ in the gas samples were measured by an online $\mathrm{CH}_{4}$ extraction system, Trace GC Ultra ${ }^{\mathrm{TM}}$ (Thermo Electron Corporation, Austin, TX, USA), a combustion furnace (ceramic tube packed with $\mathrm{CuO}, \mathrm{NiO}$, and $\mathrm{Pt}$ wires), and ThermoQuest Delta ${ }^{\text {plus }} \mathrm{XL}$ isotope ratio mass spectrometer (Thermo Finnigan). The $\delta^{13} \mathrm{C}$ derived was determined with reference to Vienna PeeDee Belemnite samples. The precision of the determination was $\pm 0.1 \%$.

\section{Archaeal and bacterial 16S rRNA gene analysis}

Aliquots of water sample $(1 \mathrm{~L})$ were aseptically filtered with a 0.22- $\mu \mathrm{m}$ membrane filter (Whatman, Japan). The filters were maintained at $-70{ }^{\circ} \mathrm{C}$ until extraction. Bulk DNA was extracted using a FastDNA SPIN kit for soil (Bio101 Systems, Carlsbad, CA, USA) according to the manufacturer's instructions. Archaeal 16S rRNA gene fragments were amplified by PCR using the archaea-specific primers AR-8F and AR-958R (DeLong 1992), and bacterial 16S rRNA gene fragments were amplified by PCR using the bacteria-specific primers BAC$27 \mathrm{~F}$ and BAC-1492R (Lane 1991). These reactions were performed according to the following protocol: $94{ }^{\circ} \mathrm{C}$ for $4 \mathrm{~min}, 35$ cycles at $94^{\circ} \mathrm{C}$ for $30 \mathrm{~s}, 56^{\circ} \mathrm{C}$ for $30 \mathrm{~s}, 72{ }^{\circ} \mathrm{C}$ for $1 \mathrm{~min}$, and finally $72{ }^{\circ} \mathrm{C}$ for $10 \mathrm{~min}$.
The PCR products of the archaeal and bacterial $16 \mathrm{~S}$ rRNA genes were cloned and transformed into competent Escherichia coli DH5 $\alpha$ cells using pGEM-T Easy Vector (Promega Corporation, Madison, WI, USA). Recombinant pGEM-T Easy vectors were checked for $16 \mathrm{~S}$ rRNA amplicon inserts by PCR using M13 primers. For the archaeal library, the right-inserted recombinant clones were sequenced. For the bacterial library, the correct clones were analyzed by amplified ribosomal DNA restriction analysis (ARDRA) using restriction enzyme Msp I (NEB) as described by Steven et al. (2007). For each restriction fragment length polymorphism (RFLP) type, one representative clone was chosen at random and sequenced.

Sequencing and phylogenetic analyses

The sequences of inserted PCR products selected from recombinant colonies were determined on an Applied Biosystems 3730xl (Applied Biosytems, Darmstadt, Germany) using M13 primers. The operational taxonomic units (OTUs) for the archaeal clone library were determined using Mothur software (Schloss et al. 2009). A 3\% distance level between sequences was used as the cutoff to define distinct OTUs. Sequences for each archaeal OTU and bacterial RFLP type were then compared with NCBI nucleotide sequence database using NCBI BLAST (http://www.ncbi.nlm. nih.gov/BLAST/). Sequences were aligned by Clustal X (Thompson et al. 1997). A phylogenetic tree was constructed in the MEGA 4 software using the neighborjoining method and bootstrap resampling analysis for 1,000 repeats (Tamura et al. 2007).

\section{Real-time PCR analysis}

The 16S rRNA genes from Methanolobus species and Clostridium species were respectively amplified using primer sets AR-8F and AR-958R (DeLong 1992) and BAC-27F and BAC-1492R (Lane 1991) to construct the plasmids to be used for a standard curve in real-time PCR. The PCR products were cloned and transformed according to the protocol described above. The plasmids were extracted using a Tianprep Mini Plasmid Kit (Tiangen Biotech, China) and quantified based on absorbance at $260 \mathrm{~nm}$ then sequenced as described above to confirm the correction of the insertion. The plasmids were then tenfold serially diluted to $10^{2}-10^{9}$ copies per microliter for both archaeal and bacterial 16S rRNA genes. Copies per microliter were calculated according to the formula mentioned by Smith et al. (2006).

SYBR Green real-time PCR was performed in Mx3000P Real-time QPCR System (Stratagene) using Maxima ${ }^{\mathrm{TM}}$ SYBR Green qPCR Master Mix (Fermentas, Hanover, MD, USA) following the modified protocols as described by the manufacturer. Archaea-specific primers AR-344F 
and AR-519R (Lane 1991; Raskin et al. 1994) and bacteriaspecific primers BAC-338F and BAC-518R (Lane 1991; Muyzer et al. 1993) were respectively used to determine the abundance of archaea and bacteria in the samples. Amplification was carried out in a total volume of $25 \mu \mathrm{L}$ containing $12.5 \mu \mathrm{L}$ of $2 \times \operatorname{ROX}, 1 \mu \mathrm{L}$ of each primer $(10 \mu \mathrm{M})$, and $1 \mu \mathrm{L}$ of sample DNA. The thermocycling program was as follows: initial denaturation for $15 \mathrm{~min}$ at $95^{\circ} \mathrm{C}$, followed by 40 cycles of $30 \mathrm{~s}$ at $95{ }^{\circ} \mathrm{C}, 30 \mathrm{~s}$ at $56^{\circ} \mathrm{C}$, and $30 \mathrm{~s}$ at $72{ }^{\circ} \mathrm{C}$. Each template DNA was analyzed in triplicate.

Measurements of potential microbial methane

To determine the potential of methane production by methanogenic archaea, enrichments were performed using water samples amended with methanogenic substrates and an anaerobic medium. The anaerobic medium was modified according to Strapoć et al. (2008). The equivalent of five samples was mixed and aliquots of water samples $(20 \mathrm{ml})$ were anaerobically injected into autoclaved $100-\mathrm{ml}$ serum bottles with an anaerobic medium, supplemented with acetate $(20 \mathrm{mM})$, methanol $(20 \mathrm{mM})$, formate $(20 \mathrm{mM}), \mathrm{H}_{2}+\mathrm{CO}_{2}(80 / 20, V / V$; $10^{5} \mathrm{~Pa}$ ), or bromoethanesulfonate (BES) $(20 \mathrm{mM})$, an inhibitor of methanogens (Gunsalus et al. 1978). Except for $\mathrm{H}_{2}+\mathrm{CO}_{2}$ supplemented bottles, the headspaces of the serum bottles were filled with pure $\mathrm{N}_{2}$ gas at $10^{5} \mathrm{~Pa}$. The enrichments were anaerobically incubated without shaking at 15,25 , and $35^{\circ}$ $\mathrm{C}$, respectively. The concentration of $\mathrm{CH}_{4}$ in the headspace was measured using GC-7890A equipped with a flame ionization detector (Agilent Technologies). All enrichments were carried out in triplicate.

\section{PCR-DGGE analysis of enrichments}

The enrichments in which methane production was observed were centrifuged. Bulk DNA extraction and PCR amplification were carried out according to the method described above using primers AR-344F with a GC clamp at the 5' end and AR-519R (Lane 1991; Raskin et al. 1994) for archaeal 16S rRNA gene PCR-DGGE analysis. PCRDGGE was performed using DCode ${ }^{\mathrm{TM}}$ system (Bio-Rad Laboratories). The optimized denaturing gradient extended from $40 \%$ to $60 \%$ in $10 \%$ acrylamide gels. Electrophoresis was performed at $60 \mathrm{~V}$ and $60{ }^{\circ} \mathrm{C}$ for $18 \mathrm{~h}$. After electrophoresis, DNA was stained with $\mathrm{EB}$ and visualized under UV light. Individual DGGE bands were excised and reamplified with the same primer sets without the GC clamp. The PCR products were purified using Gel Extraction Pure Kit (Fermentas) according to the manufacturer's instructions then sequenced and compared to the 16S rRNA gene sequences in NCBI as described above.

Nucleotide sequence accession numbers

The 16S rRNA gene sequences obtained in this study have been deposited in GenBank under accession No. JN223421 to JN223444.

\section{Results}

Properties of water produced

The temperature of the water samples ranged from 15 to $19^{\circ} \mathrm{C}$; $\mathrm{pH}$ values were from 7.5 to 7.8. The concentration of $\mathrm{Cl}^{-}$and $\mathrm{Na}^{+}$(Table 1) in the water samples was the same as reported by Shimizu et al. (2007). The $\mathrm{K}^{+}, \mathrm{Ca}^{2+}, \mathrm{Mg}^{2+}, \mathrm{NO}_{3}{ }^{-}$, and $\mathrm{NH}_{4}{ }^{+}$ were similar to those of groundwater from the coal bed in the Powder River Basin (Bates et al. 2011).

\section{Composition and stable isotopic ratios of CBM}

Methane was the predominant component of CBM ( $>95 \%)$. Other main components were $\mathrm{N}_{2}$ and $\mathrm{CO}_{2}$ at $0.04-3.15 \%$
Table 1 Physicochemical parameters of water samples

\begin{tabular}{lccccc}
\hline & SXLL-2 & SXLL-3 & SXLL-4 & SXLL-6 & SXLL-9 \\
\hline Temperature $\left({ }^{\circ} \mathrm{C}\right)$ & 15 & 19 & 17 & 17 & 18 \\
$\mathrm{pH}^{\mathrm{a}}$ & 7.62 & 7.54 & 7.49 & 7.55 & 7.78 \\
$\mathrm{SO}_{4}{ }^{2-}(\mathrm{mmol} / \mathrm{L})$ & $\mathrm{NA}^{\mathrm{b}}$ & 1.75 & 1.48 & 1.49 & 1.56 \\
$\mathrm{Cl}^{-}(\mathrm{mmol} / \mathrm{L})$ & 51.66 & 55.91 & 52.10 & 54.02 & 55.58 \\
$\mathrm{NO}_{3}{ }^{-}(\mathrm{mmol} / \mathrm{L})$ & 0.011 & 0.016 & 0.022 & 0.015 & 0.019 \\
$\mathrm{NO}_{2}^{-}\left(10^{-3} \mathrm{mmol} / \mathrm{L}\right)$ & 0.14 & 0.07 & $<0.05$ & $<0.05$ & $<0.05$ \\
$\mathrm{NH}_{4}^{+}(\mathrm{mmol} / \mathrm{L})$ & 0.13 & 0.20 & 0.11 & 0.13 & 0.14 \\
$\mathrm{Na}^{+}(\mathrm{mmol} / \mathrm{L})$ & 91.74 & 86.52 & 86.09 & 84.78 & 80.43 \\
$\mathrm{~K}^{+}(\mathrm{mmol} / \mathrm{L})$ & 0.21 & 0.22 & 0.21 & 0.22 & 0.21 \\
$\mathrm{Ca}^{2+}(\mathrm{mmol} / \mathrm{L})$ & 0.15 & 0.35 & 0.29 & 0.30 & 0.18 \\
$\mathrm{Mg}^{2+}(\mathrm{mmol} / \mathrm{L})$ & 0.84 & 1.01 & 1.23 & 1.24 & 1.30 \\
\hline
\end{tabular}


and $0.55-1.77 \%$, respectively. $\mathrm{H}_{2}, \mathrm{O}_{2}$, and $\mathrm{C}_{3} \mathrm{H}_{8}$ in the CBM were below the detection limits. The $\mathrm{C}_{1} /\left(\mathrm{C}_{2}+\mathrm{C}_{3}\right)$ ratios of the $\mathrm{CBM}$ were all $>10^{3}$. Stable carbon isotope ratios of methane $\left(\delta^{13} \mathrm{C}-\mathrm{CH}_{4}\right)$ and carbon dioxide $\left(\delta^{13} \mathrm{C}-\mathrm{CO}_{2}\right)$ ranged from $-42.28 \%$ to $-39.78 \%$ and from $-6.88 \%$ to $19.74 \%$, respectively (Table 2 ). The difference between the stable carbon isotope ratios of carbon dioxide $\left(\delta^{13} \mathrm{C}-\mathrm{CO}_{2}\right)$ might be because wells SXLL-2 and SXLL-3 aimed at the no. 5 coal seam while wells SXLL-6 and SXLL-9 aimed at the no. 8 coal seam. The no. 5 coal seam is located in the Shanxi Formation of the Lower Permian while the no. 8 coal seam is located in the Taiyuan Formation of the upper Carboniferous (Su et al. 2003).

Phylogenetic analysis of archaeal and bacterial 16S rRNA genes

A total of 48 clones in the archaeal 16S rRNA gene clone library were sequenced and divided into three OTUs (SXLL-A01 to SXLL-A03) (Fig. 2). Phylogenetic analysis showed that all of the clones in the library belonged to the family Methanosarcinaceae, one of the most common methanogenic lineages found in coal beds (Strapoć et al. 2011). Additionally, $70.83 \%$ of the clones were affiliated to Methanolobus sp. Specifically, both SXLL-A01 and SXLL-A02 were closely related to the 16S rRNA gene from the cultured organisms Methanolobus chelungpuianus (98\% identity), Methanolobus psychrophilus (96\% identity), and Methanolobus profundi ( $95 \%$ identity), which are all methylotrophic methanogens (Mochimaru et al. 2009; Wu and Lai 2011; Zhang et al. 2008). SXLL-A03 showed the highest identity to the 16S rRNA gene from the cultured organism Methanosarcina mazei ( $98 \%$ identity), which metabolizes a wide variety of substrates (Simankova et al. 2003).

A total of 159 clones in the bacterial 16S rRNA gene clone library were examined and 21 unique RFLP types were detected (Fig. 3). The majority of clones belonged to Epsilonproteobacteria and Betaproteobacteria. The clones of Epsilonproteobacteria accounted for $43.4 \%$ of the clones in the library and all of the phylotypes were closely

Table 2 Chemical compositions and stable isotope analysis of gas samples obtained from the CBM-producing wells

\begin{tabular}{|c|c|c|c|c|c|c|}
\hline \multirow[t]{2}{*}{ No. } & \multicolumn{3}{|c|}{ Composition (\%) } & \multicolumn{2}{|c|}{$\delta^{13} \mathrm{C}$ (\%о PDB) } & \multirow[t]{2}{*}{$\mathrm{C}_{1} /\left(\mathrm{C}_{2}+\mathrm{C}_{3}\right)^{\mathrm{a}}$} \\
\hline & $\mathrm{N}_{2}$ & $\mathrm{CO}_{2}$ & $\mathrm{CH}_{4}$ & $\mathrm{CH}_{4}$ & $\mathrm{CO}_{2}$ & \\
\hline SXLL-2 & 1.25 & 0.74 & 97.94 & -40.78 & -1.90 & $1,399.14$ \\
\hline SXLL-3 & 3.15 & 1.28 & 95.5 & -41.72 & -6.88 & $1,364.29$ \\
\hline SXLL-6 & 0.62 & 0.55 & 98.74 & -39.78 & 17.41 & $1,097.11$ \\
\hline SXLL-9 & 0.04 & 1.77 & 98.11 & -42.28 & 19.74 & $1,226.38$ \\
\hline
\end{tabular}

${ }^{\mathrm{a}}$ Methane/(ethane + propane)

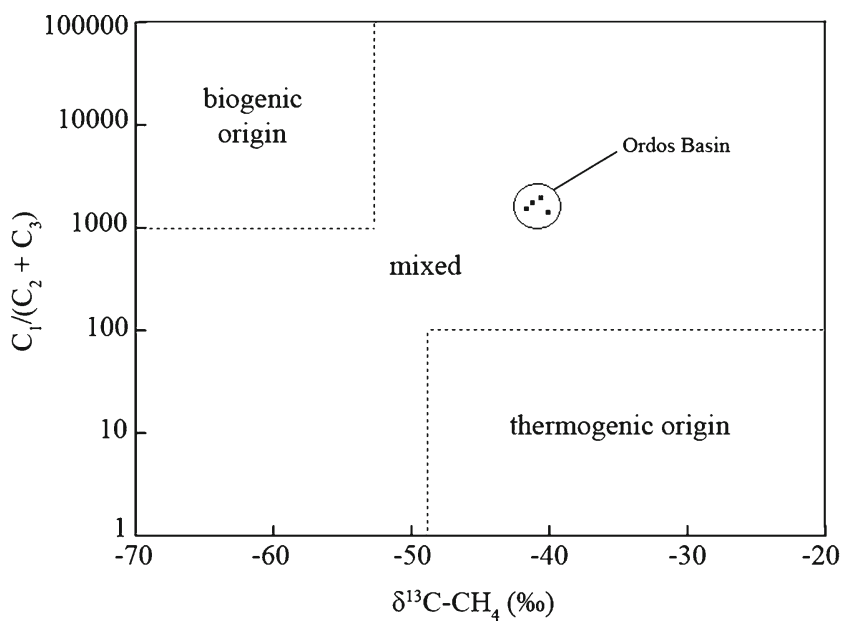

Fig. 2 Diagram of gas composition $\mathrm{C}_{1} /\left(\mathrm{C}_{2}+\mathrm{C}_{3}\right)$ [methane/(ethane + propane)] versus methane carbon isotope of the CBM from Ordos Basin. The categorization of methane origin is according to Bernard et al. (1978)

affiliated ( $>96 \%$ similarity). They showed utmost identity to the 16S rRNA gene from the cultured organism Arcobacter defluvii ( $>97 \%$ 16S rRNA sequence identity), which is able to anaerobically reduce nitrate (Collado et al. 2011). The Betaproteobacteria (39\% of the clones) consisted of three phylotypes. SXLL-B06 was closely related to the $16 \mathrm{~S}$ rRNA gene from the cultured organism Azonexus hydrophilus (99\% identity), known as a nitrate-reducing bacterium (Chou et al. 2008). Both SXLL-B11 and SXLL-B13 showed the closest match to the 16S rRNA gene from the cultured organism Thauera sp. (98\% identity), which is a denitrifying bacterium and able to degrade aromatic compounds (Mechichi et al. 2002; Shinoda et al. 2004). Sequences related to the Firmicutes (10.7\% of the clones) were clustered into eight phylotypes (Fig. 3), which were all closely related to the $16 \mathrm{~S}$ rRNA gene from the cultured sulfate-reducing or fermentative bacteria. Both SXLL-B17 and SXLL-B20 were closely related to the 16S rRNA gene from the cultured sulfate-reducing bacterium Desulfosporosinus lacus (100\% identity) (Ramamoorthy et al. 2006) and also related to Desulfosporosinus sp. (100\% identity) which is able to metabolize such aromatic compounds as syringic acid, ferulic acid, phenol, benzoate, and toluene (Liu et al. 2004). Both SXLL-B16 and SXLL-B21 showed the closest match to the 16S rRNA gene from the cultured organism Desulfotomaculum sp. ( $90 \%$ identity) which is a sulfate reducer and able to degrade $o$-xylene, $m$-xylene, and toluene (Morasch et al. 2004) and from Pelotomaculum terephthalicicum $(90 \%$ identity) which was isolated from methanogenic sludges as syntrophic phthalate isomer-degrading microbes (Qiu et al. 2004). Both SXLL-B02 and SXLLB18 were closely related to the $16 \mathrm{~S}$ rRNA gene from the cultured organism Saccharofermentans acetigenes (91\% 


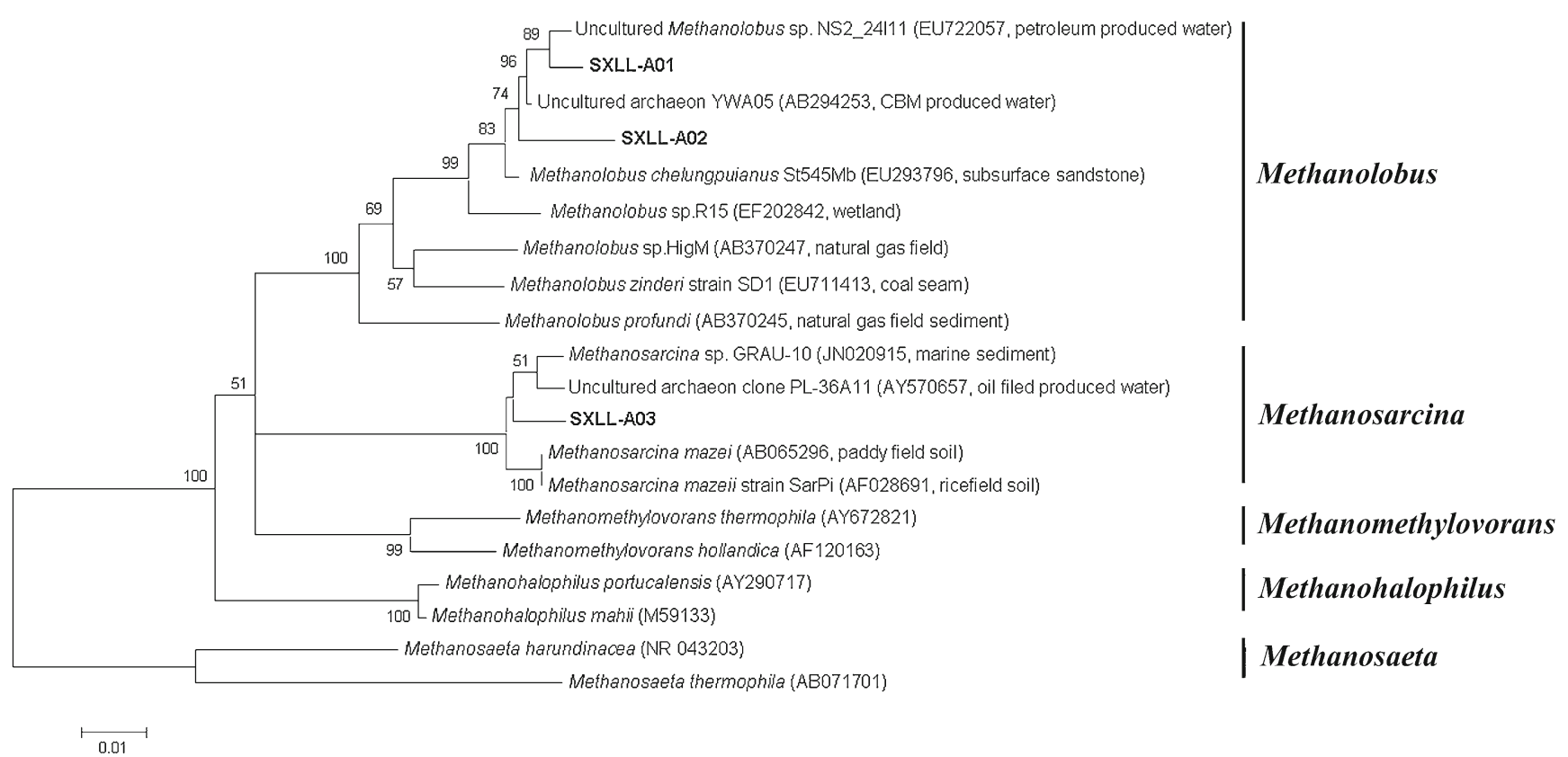

Fig. 3 Phylogenetic tree of archaeal 16S rRNA gene sequences from the water samples together with related sequences of environmental clones and cultured archaea. Bootstrap support values $(1,000$

identity), which was isolated from an upflow anaerobic sludge blanket reactor and could ferment polysaccharides (Chen et al. 2010). They were also related to the anaerobic cellulolytic bacterium Clostridium straminisolvens $(90 \%$ identity) (Kato et al. 2004). SXLL-B05 was closely related to the 16S rRNA gene from several cultured organisms of genus Acetobacterium which are acetogens and also reported to utilize $\mathrm{H}_{2}$, e.g., Acetobacterium carbinolicum (99\% identity) and Acetobacterium psammolithicum (98\% identity) (Krumholz et al. 1999; Paarup et al. 2006). SXLLB15 showed the closest match to the cultured fermentative bacteria Alkalibacter saccharofermentans (98\% identity), known as saccharolytic bacteria in the cellulolytic process (Garnova et al. 2004). Only two phylotypes, i.e., SXLL-B09 and SXLL-B19, belonged to Deltaproteobacteria (4.4\% of the clones). SXLL-B09 showed the highest identity to the 16S rRNA gene from the cultured sulfate-reducing bacteria Desulfofustis glycolicus (96\% identity) growing with glycolate (Friedrich et al. 1996) and SXLL-B19 showed the highest identity to the 16S rRNA gene from several strains of the genus Desulfomicrobium (99\% identity) which are all sulfate reducers (Hippe et al. 2003). The residual phylotypes SXLL-B04 and SXLL-B07 were defined as unclassified bacteria, with $<85 \%$ identity to the cultured organism.

\section{Real-time PCR assay}

Quantification of the total archaeal and bacterial community in the water produced was carried out. All of the samples were quantified in triplicate, and the average value was converted to replicates) above $50 \%$ are shown at nodes. The scale bar represents $1 \%$ estimated sequence divergence

16S rRNA gene copies per milliliter of water. The copy number of archaeal $16 \mathrm{~S}$ rRNA genes in the water sample was $7.2 \times 10^{4}$, while that of bacterial $16 \mathrm{~S}$ rRNA genes was $3.43 \times 10^{7} / \mathrm{ml}$, which was two orders of magnitude higher than the CBM reservoir in Hokkaido (Shimizu et al. 2007).

Potential for microbial methane production

Methane production was observed only in the enrichments supplemented with methanol, and high rates of methane production were found in the enrichments incubated at 25 and $35^{\circ} \mathrm{C}$ (Fig. 4). The maximum methane production rate for $25{ }^{\circ} \mathrm{C}$ was $83.2 \mu \mathrm{mol} /$ day (between 20 and 24 days) compared to $203.7 \mu \mathrm{mol} /$ day (between 6 and 8 days) at $35{ }^{\circ} \mathrm{C}$, as increasing temperature leads to increasing methane production rates.

The archaeal communities in the enrichments were analyzed by PCR-DGGE. Five to seven DGGE bands were detected in each enrichment (Fig. 5) and a total of nine distinct archaeal bands were excised and sequenced (Table 3). The DGGE profiles were very similar between the enrichments, especially the enrichments incubated at 25 and $35^{\circ} \mathrm{C}$ (Fig. 5). A few bands present in enrichments were not detected in the water sample, which might be due to the strong selective pressure caused by the amended anaerobic medium and the high concentration of supplemented methanol. Five bands showed high similarity ( $>98 \%$ ), i.e., SLG-A01, SLG-A02, SLG-A05, SLG-A07, and SLG-A08. They were all closely related to the 16S rRNA gene from the cultured mesophilic methanol and trimethylamine-using methanogen 


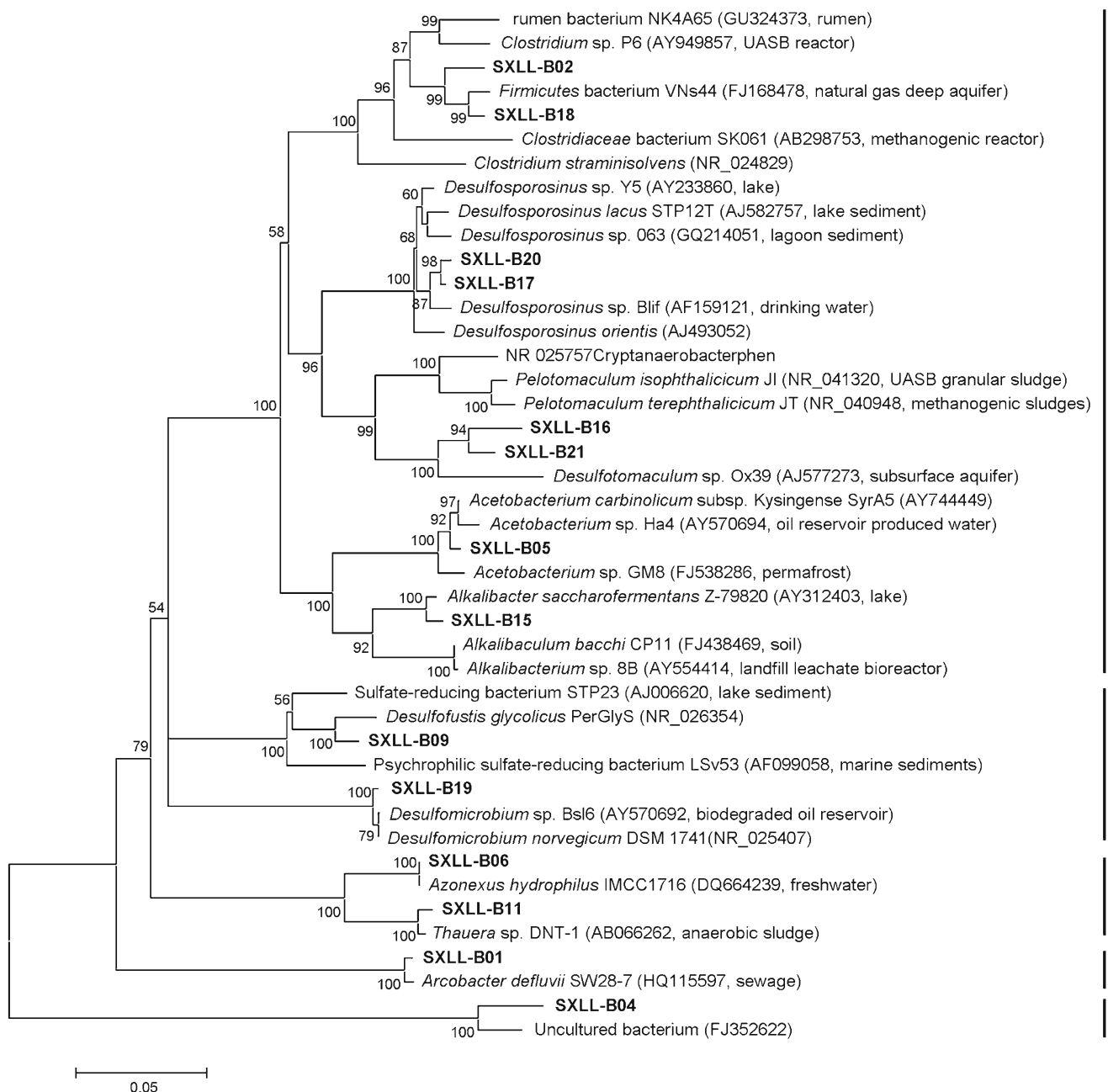

\section{Firmicutes}

Deltaproteobacteria

Betaproteobacteria

Epsilonproteobacteria Unclassified bacteria

Fig. 4 Phylogenetic tree of bacterial 16S rRNA gene sequences from the water samples together with related sequences of environmental clones and cultured bacteria. Bootstrap support values $(1,000$ replicates) above $50 \%$ are shown at nodes. The scale bar represents $5 \%$ estimated sequence divergence

in both enrichments. The same archaeal communities in the enrichments incubated at 25 and $35{ }^{\circ} \mathrm{C}$ and the dominance of methylotrophic methanogen were in accordance with the observation of methane production. Although the DGGE analysis showed that methanogens existed in the enrichment incubated at $15{ }^{\circ} \mathrm{C}$ (SLG-A02, A03, A08, and A09), significant methane production was not observed (Fig. 4). This might be because that the temperature was not optimal for the production of methane, given that the temperature range for growth was 20 to $42{ }^{\circ} \mathrm{C}$ for $M$. horonobensis (Shimizu et al. 2011), 25 to $50^{\circ} \mathrm{C}$ for M. congolense (Cuzin et al. 2001), and 24 to $45^{\circ} \mathrm{C}$ for M. chelungpuianus (Wu and Lai 2011).

\section{Discussion}

We determined the chemical composition and stable isotopic ratios of $\mathrm{CBM}$ derived from the $\mathrm{CBM}$ reservoir associated ism, suggesting that the same archaeal communities existed 

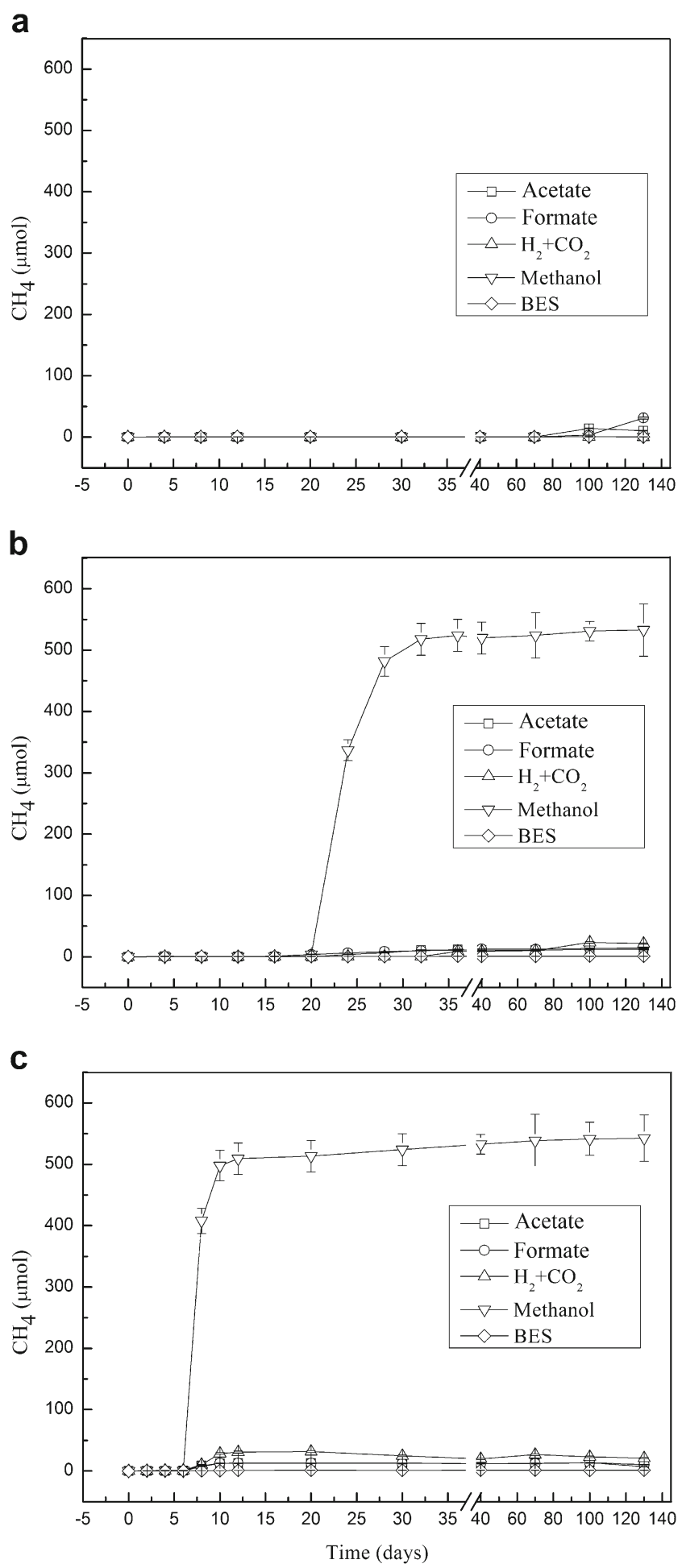

Fig. 5 Methane production from the water samples supplemented with acetate (open square), formate (open circle), $\mathrm{H}_{2}+\mathrm{CO}_{2}$ (open triangle), methanol (open inverted triangle), and BES (open diamond). The enrichments were incubated at $15{ }^{\circ} \mathrm{C}(\mathbf{a}), 25^{\circ} \mathrm{C}(\mathbf{b})$, and $35^{\circ} \mathrm{C}(\mathbf{c})$. Values are the mean of three replicates indicating the amount of methane accumulated in the headspaces of the culture bottles. Errors bars (where visible) represent the standard deviation
Table 3 Archaeal 16S rRNA gene sequences derived from DGGE bands

\begin{tabular}{|c|c|c|}
\hline Band & Phylogenetic group & $\begin{array}{l}\text { Closest cultivated } \\
\text { species ( } \% \text { identity) }\end{array}$ \\
\hline SLG-A01 & Methanosarcinaceae & $\begin{array}{l}\text { Methanolobus } \\
\text { chelungpuianus }(99 \%)\end{array}$ \\
\hline SLG-A02 & Methanosarcinaceae & $\begin{array}{l}\text { Methanolobus } \\
\text { chelungpuianus (97\%) }\end{array}$ \\
\hline SLG-A03 & Methanosarcinaceae & $\begin{array}{l}\text { Methanosarcina } \\
\text { horonobensis (94\%) }\end{array}$ \\
\hline SLG-A04 & Nitrosopumilaceae & $\begin{array}{l}\text { Candidatus } \\
\quad \text { Nitrosopumilus }(91 \%)\end{array}$ \\
\hline SLG-A05 & Methanosarcinaceae & $\begin{array}{l}\text { Methanolobus } \\
\text { chelungpuianus (99\%) }\end{array}$ \\
\hline SLG-A06 & Nitrosopumilaceae & $\begin{array}{l}\text { Candidatus } \\
\quad \text { Nitrosopumilus (91\%) }\end{array}$ \\
\hline SLG-A07 & Methanosarcinaceae & $\begin{array}{l}\text { Methanolobus } \\
\text { chelungpuianus (99\%) }\end{array}$ \\
\hline SLG-A08 & Methanosarcinaceae & $\begin{array}{l}\text { Methanolobus } \\
\text { chelungpuianus (97\%) }\end{array}$ \\
\hline SLG-A09 & Methanobacteriaceae & $\begin{array}{l}\text { Methanobacterium } \\
\text { congolense }(95 \%)\end{array}$ \\
\hline
\end{tabular}

with the Ordos Basin and the cross-plot of $\mathrm{C}_{1} /\left(\mathrm{C}_{2}+\mathrm{C}_{3}\right)$ over $\delta^{13} \mathrm{C}-\mathrm{CH}_{4}$ typifies methane of mixed biogenic and thermogenic origin (Bernard et al. 1978) (Fig. 6).

To identify methanogenic archaea in the water samples, we determined the archaeal community using 16S rRNA gene clone library. The phylogenetic analysis indicated that all archaea were related to methanogens belonging to the family Methanosarcinaceae (Fig. 2). The limited archaeal diversity was not surprising as coal beds are nutrient-limited habitats. Similarly, only one RFLP-type closely related to Methanobacterium alcaliphilum was detected in the water produced in the CBM reservoir in the Gippsland Basin (Midgley et al. 2010). The majority of the species were closely related to Methanolobus, an obligate methylotrophic methanogen (Mochimaru et al. 2009; Wu and Lai 2011). The remainder of the species were closely related to Methanosarcina, which is also known to utilize the methylotrophic pathway (Simankova et al. 2003). Furthermore, high rates of methane production were observed in the enrichments amended with methanol and incubated at 25 and $35^{\circ}$ C (Fig. 4). The primary methanogenic archaea propagated on these enrichments were closely related to the cultured methanogens M. chelungpuianus and M. horonobensis (Table 3; Fig. 5), which are both methylotrophic methanogens (Shimizu et al. 2011; Wu and Lai 2011). M. chelungpuianus was also the dominant archaea detected in the water samples (Fig. 2). Taken together, the current phylogenetic and physiological evidence strongly suggests that the biogenic CBM in the Liulin District associated with the Eastern Ordos Basin is produced by methylotrophic methanogenesis. 


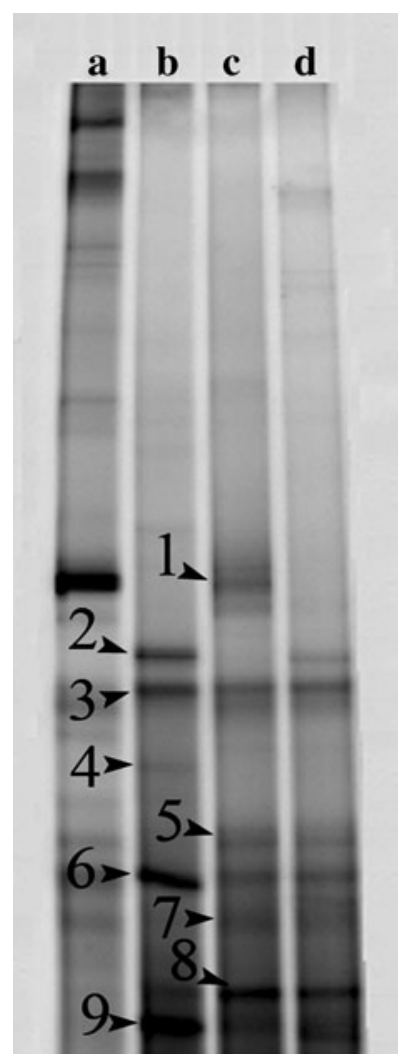

Fig. 6 DGGE profiles of archaeal 16S rRNA genes amplified from microbial community DNA obtained from water sample and enrichments: $a$ water sample, $b$ enrichment incubated at $15^{\circ} \mathrm{C}, c$ enrichment incubated at $25{ }^{\circ} \mathrm{C}, d$ enrichment incubated at $35^{\circ} \mathrm{C}$. Marked bands were selected for sequencing

The question remains as to why methylotrophic methanogenesis predominates in that site as it was rarely reported in other CBM reservoirs (Shimizu et al. 2007; Strapoć et al. 2010). We examined the bacterial community in the water produced using a $16 \mathrm{~S}$ rRNA gene clone library to better understand the coal biodegradation by syntrophic bacteria at that site.

The prevailing view is that the growth of methanogens associated with CBM reservoirs was dependent on coal biodegradation by syntrophic bacteria. Coal is extremely rich in complex organic matter often dominated by aromatic and largely lignin-derived macromolecules, which are attractive carbon sources for microbial biodegradation (Strapoć et al. 2008). Several intermediates are factors in the biodegradation of coal, e.g., aromatic and aliphatic monomers, propionate, butyrate, valarate, succinate, alcohols, and various other substrates, which are precursors for methanogenesis (Strapoć et al. 2010)

Several clones in the library were closely related to fermentative bacteria. The biodegradation of coal in this site could be potentially performed by the clones associated with Firmicutes. Various representative clones are found in our library, e.g., Clostridium sp. degrades cellulose, xylan, and polysaccharides (Chen et al. 2010; Kato et al. 2004; Zhilina et al. 2005), Desulfosporosinus sp. utilizes aromatic compounds (Liu et al. 2004), and Acetobacterium sp., Alkalibacter sp., and Desulfotomaculum sp. use monosaccharide and monoaromatic hydrocarbons as substrates (Garnova et al. 2004; Morasch et al. 2004; Paarup et al. 2006). Methanol, acetate, $\mathrm{CO}_{2}, \mathrm{H}_{2}$, and other substrates for methanogens are thereby produced. Certain sulfate-reducing bacteria found in our library might also grow by fermentation of coal components at the site as Desulfotomaculum sp. is able to degrade o-xylene, $m$-xylene, and toluene (Morasch et al. 2004).

Various relatives of the fermentative bacteria detected in our library were related to acetogens or facultative acetogens using $\mathrm{H}_{2}$ as an electron donor such as clones related to Acetobacterium (Krumholz et al. 1999; Paarup et al. 2006), Alkalibaculum (Allen et al. 2010), and Desulfosporosinus (Ramamoorthy et al. 2006). The presence of acetogens might explain the non-detection of hydrogenotrophic methanogens. However, the product acetate would simulate sulfate reduction at the site because sulfate-reducing bacteria were also found in our library, e.g., Desulfotomaculum, Desulfofustis, Desulfomicrobium, and Desulfosporosinus. Sulfate-reducing bacteria would outcompete methanogens for acetate, resulting in the non-detection of acetoclastic methanogens (Oremland and Polcin 1982). Sulfate-reducing bacteria would not compete with methanogens with methanol, allowing methanogenesis and sulfate reduction to operate simultaneously at the site (Oremland and Polcin 1982). The presence of both acetogens and sulfate-reducing bacteria led to the predominance of methylotrophic methanogens. Methanol might be produced in the process of biodegrading the lignin component of coal as it has been reported as a biodegradation product of the natural methoxylated aromatics which are the building blocks of lignin (Donnelly and Dagley 1980).

Corresponding to other CBM reservoirs (Penner et al. 2010), an abundance of clones affiliated with nitratereducing bacteria was also detected in the bacterial library (SXLL-B06 and all clones related to Epsilonproteobacteria), which are potentially involved in the cycling of inorganic nitrogen together with denitrifying bacteria (SXLLB11 and SXLL-B13). ARDRA might underestimate the actual bacterial diversity and all of the metabolic considerations above were solely obtained from DNA sequences. A deeper evaluation of bacterial diversity using nextgeneration sequencing, e.g., 454 pyrosequencing, and further determination of the activities and functions of these bacteria using stable isotope probing and cultivation are necessary for further investigation.

In conclusion, the composition and stable isotopic ratios of the CBM implied a mixed biogenic and thermogenic origin for the Liulin CBM. The available microbiological data showed that fermentative, sulfate-reducing, and nitratereducing bacteria were a factor in coal biodegradation, 
providing substrates for methylotrophic methanogenic archaea to produce methane. These results suggested that past and ongoing biodegradation of coal by methylotrophic methanogens and syntrophic bacteria, as well as thermogenic CBM production, contributed to the Liulin CBM reserves associated with Eastern Ordos Basin.

Acknowledgements We are grateful to China United Coalbed Methane Co., Ltd., for helping with sampling opportunities on the water produced. This work was supported by National Science and Technology Major Project, China (2011ZX05060-005 and 2009ZX05039-003).

\section{References}

Allen TD, Caldwell ME, Lawson PA, Huhnke RL, Tanner RS (2010) Alkalibaculum bacchi gen. nov., sp. nov., a CO-oxidizing, ethanol-producing acetogen isolated from livestock-impacted soil. Int J Syst Evol Microbiol 60:2483-2489

Bates BL, McIntosh JC, Lohse KA, Brooks PD (2011) Influence of groundwater flowpaths, residence times and nutrients on the extent of microbial methanogenesis in coal beds: Powder River Basin, USA. Chem Geol 284:45-61

Bernard BB, Brooks JM, Sackett WM (1978) Light hydrocarbons in recent Texas continental shelf and slope sediments. J Geophys Res 83:4053-4061

Chen S, Niu L, Zhang Y (2010) Saccharofermentans acetigenes gen nov, sp nov, an anaerobic bacterium isolated from sludge treating brewery wastewater. Int J Syst Evol Microbiol 60:2735-2738

Chou JH, Jiang SR, Cho JC, Song J, Lin MC, Chen WM (2008) Azonexus hydrophilus sp nov, a nifH gene-harbouring bacterium isolated from freshwater. Int J Syst Evol Microbiol 58:946-951

Collado L, Levican A, Perez J, Figueras MJ (2011) Arcobacter defluvii sp nov, isolated from sewage samples. Int J Syst Evol Microbiol 61:2155-2161

Cuzin N, Ouattara AS, Labat M, Garcia JL (2001) Methanobacterium congolense sp nov, from a methanogenic fermentation of cassava peel. Int J Syst Evol Microbiol 51:489-493

DeLong EF (1992) Archaea in coastal marine environments. Proc Natl Acad Sci U S A 89:5685-5689

Ding S, Zhu J, Zhen B, Liu Z, Liu Q (2011) Characteristics of high rank coal bed methane reservoir from the Xiangning Mining Area, Eastern Ordos Basin, China. Energ Explor Exploit 29:33-48

Donnelly M, Dagley S (1980) Production of methanol from aromatic acids by Pseudomonas putida. J Bacteriol 142:916-924

Flores RM, Rice CA, Stricker GD, Warden A, Ellis MS (2008) Methanogenic pathways of coal-bed gas in the Powder River Basin, United States: the geologic factor. Int J Coal Geol 76:52-75

Friedrich M, Springer N, Ludwig W, Schink B (1996) Phylogenetic positions of Desulfofustis glycolicus gen. nov., sp. nov. and Syntrophobotulus glycolicus gen. nov., sp. nov., two new strict anaerobes growing with glycolic acid. Int J Syst Evol Microbiol 46:1065-1069

Garnova ES, Zhilina TN, Tourova TP, Kostrikina NA, Zavarzin GA (2004) Anaerobic, alkaliphilic, saccharolytic bacterium Alkalibacter saccharofermentans gen. nov., sp. nov. from a soda lake in the Transbaikal region of Russia. Extremophiles 8:309-316

Green MS, Flanegan KC, Gilcrease PC (2008) Characterization of a methanogenic consortium enriched from a coal bed methane well in the Powder River Basin, USA. Int J Coal Geol 76:34-45

Gunsalus RP, Romesser JA, Wolfe RS (1978) Preparation of coenzyme $\mathrm{M}$ analogs and their activity in the methyl coenzyme $\mathrm{M}$ reductase system of Methanobacterium thermoautotrophicum. Biochemistry 17:2374-2377
Harris SH, Smith RL, Barker CE (2008) Microbial and chemical factors influencing methane production in laboratory incubations of low-rank subsurface coals. Int J Coal Geol 76:46-51

Hippe H, Vainshtein M, Gogotova G, Stackebrandt E (2003) Reclassification of Desulfobacterium macestii as Desulfomicrobium macestii comb. nov. Int J Syst Evol Microbiol 53:1127-1130

Kato S, Haruta S, Cui ZJ, Ishii M, Yokota A, Igarashi Y (2004) Clostridium straminisolvens sp. nov., a moderately thermophilic, aerotolerant and cellulolytic bacterium isolated from a cellulosedegrading bacterial community. Int J Syst Evol Microbiol 54:2043-2047

Krumholz LR, Harris SH, Tay ST, Suflita JM (1999) Characterization of two subsurface H-2-utilizing bacteria, Desulfomicrobium hypogeium sp nov and Acetobacterium psammolithicum sp nov., and their ecological roles. Appl Environ Microbiol 65:2300-2306

Lane D (1991) 16S/23S rRNA sequencing. In: Stackebrandt E, Goodfellow M (eds) Nucleic acid techniques in bacterial systematics. Wiley, New York, pp 115-175

Liu A, Garcia-Dominguez E, Rhine E, Young L (2004) A novel arsenate respiring isolate that can utilize aromatic substrates. FEMS Microbiol Ecol 48:323-332

Matsutani N, Nakagawa T, Nakamura K, Takahashi R, Yoshihara K, Tokuyama T (2009) Enrichment of a novel marine ammoniaoxidizing archaeon obtained from sand of an eelgrass zone. Microb Environ 26:23-29

Mechichi T, Stackebrandt E, Gad'on N, Fuchs G (2002) Phylogenetic and metabolic diversity of bacteria degrading aromatic compounds under denitrifying conditions, and description of Thauera phenylacetica sp. nov., Thauera aminoaromatica sp. nov., and Azoarcus buckelii sp. nov. Arch Microbiol 178:26-35

Midgley DJ, Hendry P, Pinetown KL, Fuentes D, Gong S, Mitchell DL, Faiz M (2010) Characterisation of a microbial community associated with a deep, coal seam methane reservoir in the Gippsland Basin, Australia. Int J Coal Geol 82:232-239

Mochimaru H, Tamaki H, Hanada S, Imachi H, Nakamura K, Sakata S, Kamagata Y (2009) Methanolobus profundi sp. nov., a methylotrophic methanogen isolated from deep subsurface sediments in a natural gas field. Int J Syst Evol Microbiol 59:714-718

Morasch B, Schink B, Tebbe CC, Meckenstock RU (2004) Degradation of o-xylene and $\mathrm{m}$-xylene by a novel sulfate-reducer belonging to the genus Desulfotomaculum. Arch Microbiol 181:407-417

Muyzer G, de Waal EC, Uitterlinden AG (1993) Profiling of complex microbial populations by denaturing gradient gel electrophoresis analysis of polymerase chain reaction-amplified genes coding for 16S rRNA. Appl Environ Microbiol 59:695-700

Oremland RS, Polcin S (1982) Methanogenesis and sulfate reduction: competitive and noncompetitive substrates in estuarine sediments. Appl Environ Microbiol 44:1270-1276

Paarup M, Friedrich MW, Tindall BJ, Finster K (2006) Characterization of the psychrotolerant acetogen strain SyrA5 and the emended description of the species Acetobacterium carbinolicum. Anton Leeuw 89:55-69

Penner T, Foght J, Budwill K (2010) Microbial diversity of western Canadian subsurface coal beds and methanogenic coal enrichment cultures. Int J Coal Geol 82:81-93

Pfeiffer RS, Ulrich GA, Finkelstein M (2010) Chemical amendments for the stimulation of biogenic gas generation in deposits of carbonaceous material. US Patent No. 7696132

Qiu YL, Sekiguchi Y, Imachi H, Kamagata Y, Tseng IC, Cheng SS, Ohashi A, Harada H (2004) Identification and isolation of anaerobic, syntrophic phthalate isomer-degrading microbes from methanogenic sludges treating wastewater from terephthalate manufacturing. Appl Environ Microbiol 70:1617-1626

Ramamoorthy S, Sass H, Langner H, Schumann P, Kroppenstedt R, Spring S, Overmann J, Rosenzweig R (2006) Desulfosporosinus lacus sp. nov., a sulfate-reducing bacterium isolated from pristine 
freshwater lake sediments. Int J Syst Evol Microbiol 56:27292736

Raskin L, Stromley J, Rittmann B, Stahl D (1994) Group-specific 16S rRNA hybridization probes to describe natural communities of methanogens. Appl Environ Microbiol 60:1232-1240

Schloss PD, Westcott SL, Ryabin T, Hall JR, Hartmann M, Hollister EB, Lesniewski RA, Oakley BB, Parks DH, Robinson CJ (2009) Introducing Mothur: open-source, platform-independent, community-supported software for describing and comparing microbial communities. Appl Environ Microbiol 75:7537-7541

Scott AR, Kaiser W, Ayers WB (1994) Thermogenic and secondary biogenic gases, San Juan Basin, Colorado and New Mexicoimplications for coal bed gas producibility. Bull Am Assoc Petrol Geol 78:1186-1209

Shimizu S, Akiyama M, Naganuma T, Fujioka M, Nako M, Ishijima Y (2007) Molecular characterization of microbial communities in deep coal seam groundwater of northern Japan. Geobiology 5:423-433

Shimizu S, Upadhye R, Ishijima Y, Naganuma T (2011) Methanosarcina horonobensis sp. nov., a methanogenic archaeon isolated from a deep subsurface Miocene formation. Int J Syst Evol Microbiol 61:2503-2507

Shinoda Y, Sakai Y, Uenishi H, Uchihashi Y, Hiraishi A, Yukawa H, Yurimoto H, Kato N (2004) Aerobic and anaerobic toluene degradation by a newly isolated denitrifying bacterium, Thauera $\mathrm{sp}$. strain DNT-1. Appl Environ Microbiol 70:1385-1392

Simankova MV, Kotsyurbenko OR, Lueders T, Nozhevnikova AN, Wagner B, Conrad R, Friedrich MW (2003) Isolation and characterization of new strains of methanogens from cold terrestrial habitats. Syst Appl Microbiol 26:312-318

Smith CJ, Nedwell DB, Dong LF, Osborn AM (2006) Evaluation of quantitative polymerase chain reaction-based approaches for determining gene copy and gene transcript numbers in environmental samples. Environ Microbiol 8:804-815

Steven B, Briggs G, McKay CP, Pollard WH, Greer CW, Whyte LG (2007) Characterization of the microbial diversity in a permafrost sample from the Canadian high Arctic using culture-dependent and culture-independent methods. FEMS Microbiol Ecol 59:513523
Strapoć D, Mastalerz M, Eble C, Schimmelmann A (2007) Characterization of the origin of coal bed gases in southeastern Illinois Basin by compound-specific carbon and hydrogen stable isotope ratios. Org Geochem 38:267-287

Strapoć D, Picardal FW, Turich C, Schaperdoth I, Macalady JL, Lipp JS, Lin YS, Ertefai TF, Schubotz F, Hinrichs KU, Mastalerz M, Schimmelmann A (2008) Methane-producing microbial community in a coal bed of the Illinois Basin. Appl Environ Microbiol 74:2424-2432

Strapoć D, Ashby M, Wood L, Levinson R, Huizinga B (2010) Significant contribution of methyl/methanol-utilising methanogenic pathway in a subsurface biogas environment. In: Skovhus T, Whitby C (eds) Applied microbiology and molecular biology in oilfield systems. Springer, pp 211-216

Strapoć D, Mastalerz M, Dawson K, Macalady J, Callaghan AV, Wawrik B, Turich C, Ashby M (2011) Biogeochemistry of microbial coal-bed methane. Annu Rev Earth Pl Sc 39:617-656

Su X, Zhang L, Zhang R (2003) The abnormal pressure regime of the Pennsylvanian No. 8 coal bed methane reservoir in Liulin-Wupu District, Eastern Ordos Basin, China. Int J Coal Geol 53:227-239

Tamura K, Dudley J, Nei M, Kumar S (2007) MEGA4: Molecular Evolutionary Genetics Analysis (MEGA) software version 4.0. Mol Biol Evol 24:1596-1599

Thompson JD, Gibson TJ, Plewniak F, Jeanmougin F, Higgins DG (1997) The CLUSTAL X windows interface: flexible strategies for multiple sequence alignment aided by quality analysis tools. Nucleic Acids Res 25:4876-4882

Wu SY, Lai MC (2011) Methanogenic archaea isolated from Taiwan's Chelungpu Fault. Appl Environ Microbiol 77:830-838

Zhang G, Jiang N, Liu X, Dong X (2008) Methanogenesis from methanol at low temperatures by a novel psychrophilic methanogen, "Methanolobus psychrophilus" sp. nov., prevalent in Zoige Wetland of the Tibetan Plateau. Appl Environ Microbiol 74:6114 6120

Zhilina T, Kevbrin V, Tourova T, Lysenko A, Kostrikina N, Zavarzin G (2005) Clostridium alkalicellum sp. nov., an obligately alkaliphilic cellulolytic bacterium from a soda lake in the Baikal region. Microbiology 74:557-566 